\title{
Improvement of Formation and Implementation of Deposit Policy in Russian Commercial Banks
}

\author{
V.A. Manyaeva ${ }^{1}$, S.V. Rykov ${ }^{2}, M . B$. Tershukova $^{3}$, and L.N. Milova ${ }^{4}$ \\ *Corresponding author: manyaeva58@mail.ru. \\ ${ }^{1}$ Samara State University of Economics, Samara, Russia
}

\begin{abstract}
Under current market conditions, the problem of attracting available cash assets of natural and legal persons to bank deposits is one of the urgent tasks in the banking sector of the Russian Federation. Under circumstances of high competition and instability in financial markets, the issue of formation, implementation and objective assessment of deposit policy in commercial banks is becoming increasingly important. Reasonable deposit policy should take into account the selected priorities for further growth and improvement of quantitative and qualitative indicators of bank activity, its customers' characteristics, and socio-economic conditions in the country. Deposit policy has a great impact on the liquidity and bank ability to meet payments. The authors studied the modern scientific idea to form and implement deposit policy of commercial banks in the process of flexible management of banking passives under the real state of the Russian financial market, and identified directions to improve formation and implementation of deposit policy in Russian commercial banks.
\end{abstract}

Keywords: bank deposit, commercial banks, deposit policy, deposit policy evaluation, deposit services.

\section{Introduction}

One of the main tasks to improve the commercial bank activities in order to attract deposits is to use effective methods and mechanisms to manage borrowings for benefit of all groups of participants: founders, borrowers, depositors and bank staff. The formation of the optimal volume of deposit resources for a long term with the lowest use costs is possible with effective management of active and passive operations by commercial banks. At the same time, the main motivation for the owners who have available cash assets is the amount of deposit payment and return guarantee.

Reasonable deposit policy should take into account the selected priorities for further growth and improvement of quantitative and qualitative indicators of bank activity, its customers' characteristics, and socio-economic conditions in the country. Deposit policy has a great impact on the liquidity and bank ability to meet payments. To strengthen the deposit base, commercial banks need to constantly improve their deposit policy, which is aimed at the deposit attractiveness and provides bank depositors with social and economic protection under the conditions of current loss of funds value. This determines the relevance, purpose and objectives of the paper.

\section{Problem Statement}

The theoretic and practical analysis of formation and implementation of deposit policy in commercial banks showed that many problems in this area need to be solved taking into account the current conditions of banking system functioning in the Russian Federation: economic sanctions, lack of access to external borrowing markets, decrease in real incomes of the population, limitation of available cash assets in the real sector of economy, etc.

The Russian scientists and others dedicated their scientific works to theoretic researches in banking, and formation and implementation of deposit policy of commercial banks [1-2, 3, 4, 6-9].

To improve the organizational basis for formation and implementation of deposit policy, we need to develop the deposit services quality through its evaluation. National scientists $[5,7,10]$ and others, as well as foreign scientists $[11$, $12]$ and others devoted their works to this line of research.

Studies on deposit policy assessment are presented in the works of O.D. Zhilan and M.R. Danilova [13], M.S. Maramygin and D.A. Suplakov [14], V.S. Potapov and M.A. Potapova [15], V. A. Savinova and T.E. Borlakova [16], L.I. Yuzvovich and E A. Trofimova [17] and others.

For the successful formation and implementation of deposit policy, commercial banks need new scientific approaches and organizational governance, guidance paper on the deposit portfolio analysis, and evaluation of deposit policy effectiveness that meet the current conditions of the Russian banking system. Precisely, this scientific target involves the development of ways to improve formation and implementation of deposit policy of commercial banks. 


\section{Research Questions}

The following research questions are identified in this study:

- what is the quality content of bank deposit services, what are their quality indicators,

- how is the quality of deposit banking services assessed,

- how is the effectiveness of the bank deposit policy evaluated.

\section{Purpose of the Study}

The purpose of the study is to develop scientific and methodological foundations and elaborate practical recommendations to improve formation and implementation of deposit policy of commercial banks that meets the requirements of the modern Russian banking system. The developed scientific and methodological regulations contribute to the enrichment of the banking theory. Practical recommendations ensure effective implementation of deposit policy of commercial banks.

\section{Research Methods}

To develop scientific and methodical bases and elaborate practical recommendations on improvement of formation and implementation of deposit policy of the commercial banks that meets the requirements of modern development trends in the Russian deposit market, we need:

- to interpret the quality content of bank deposit services and define their quality indicators,

- to develop practical recommendations to improve the quality of deposit services in commercial banks on the basis of the SERVQUAL model that provides a survey of commercial banks depositors, using the proposed questionnaires and the order of processing and criteria for the survey results interpretation according to five indicators for the deposit service quality,

- to propose a methodology for performance evaluation of deposit policy of commercial banks that contains a set of evaluation procedures to assess banking soundness and profitability, and also allows to assess the utilization efficiency of deposit resources of commercial banks.

\section{Findings}

\subsection{The quality content of bank deposit services and quality indicators.}

When implementing deposit policy, the bank provides clients with deposit services. It sets up bank settlement accounts and current accounts, issues bank certificates and debit cards, and makes fixed-term deposit accounts to persons and corporate entities.

Under the current conditions of increased bank competition in the deposit services market, the question to improve the deposit service quality becomes especially actual. In addition, interest rate cut by the Central Bank of the Russian Federation, in recent years, does not allow banks, as previously, actively apply price instruments to stimulate attraction of financial resources to deposits. That is why the improvement of the deposit services quality plays a crucial role in deposit portfolio formation.

The deposit services quality is a set of characteristics and properties of the deposit, which enables the commercial bank to meet the expected depositor's needs.

It is proposed to define a set of quality indicators for deposit services provided by commercial banks to their depositors. First of all, they are:

- reliability in providing deposit services, that is to say, a guarantee that the client will collect money invested in the bank and accrued interest,

- timeliness, that is to say, deposit service provision strictly at the required time for the client,

- social and psychological indicator, that is to say, polite treatment with depositors by the bank employees, as well as comfort with quick requests and wishes,

- availability, that is to say, enabling the client to use the deposit service offered by the bank without obstruction,

- communication skills, that is to say, providing clients with necessary information, including the deposit services use.

\subsection{Quality evaluation of bank deposit services.}

To determine the deposit services quality, the algorithm of SERVQUAL model was tested in the study. The branch of public joint-stock company "Sberbank of Russia" was chosen as the object of the empirical research in the survey.

The indicator of deposit service quality is calculated by the formula

$$
Q=P-E,
$$


where $Q$ - quality indicator,

$P$ - perception indicator,

$E$ - expectancy indicator.

If the quality indicator $\mathrm{Q}$ tends to zero, it means that consumer's expectations coincide with the perceived quality after the fact. If there is a positive expectation value $\mathrm{E}$, the quality indicator $\mathrm{Q}$ will be negative. At the highest value of perception, $\mathrm{P}$ will be positive.

The calculation of the quality coefficient in reference to the bank customers' expectations, i.e. potential consumers of deposit services, is made by the formula

$$
Q_{1}=(\bar{E}-\bar{P}) \div \bar{E} \times 100,
$$

where $Q_{1}$ - quality ratio in reference to expectations,

$\bar{E}$ - average value of expected quality level,

$\bar{P}$ - average value of perceived quality level.

In the study, the basic model questionnaires "Perception" and "Expectation" were developed. They allowed to commensurate the expectations and perceptions of the deposit services quality received by commercial bank clients. The questions are grouped into blocks according to five quality indicators: tangibility, reliability, sympathy, confidence and empathy. According to the model, materiality, reliability, sympathy, conviction and empathy are recognized as evaluation criteria. The above-mentioned questionnaires, developed by the authors, were tested in the course of the survey of various client groups of the branch of PJSC "Sberbank of Russia", which allowed us to identify how the services provided to clients, in their perception, correspond to the expected and planned bank results.

The practical application of the developed questionnaire and methodology, consisting of a number of successive stages, in general, will provide the bank with information about the strengths and weaknesses in formation and implementation of deposit policy, assess the deposit services quality, and identify measures to improve the services quality.

\subsection{Assessment of efficiency of bank deposit policy.}

The bank deposit policy should be effective, that is to say, it should allow rational and profitable use of the resources involved in deposits, ensuring the necessary level of bank profitability and compliance with mandatory liquidity standards of the Central Bank of the Russian Federation.

The authors defined the stages of performance evaluation of bank deposit policy: assessment of the bank deposit sourcing results, assessment of the deposit resources stability, assessment of the effective use of bank deposit funds, general assessment of the deposit policy effectiveness in order to determine reserves to increase profitability and ensure bank liquidity. During these stages, the bank draws conclusions about the implemented policy strategy to attract deposits.

To assess the effectiveness of deposit policy in the commercial bank, we proposed a set of indicators (table 1).

Table 1. Set of indicators to assess deposit policy of the commercial bank.

\begin{tabular}{|l|l|}
\hline \multicolumn{1}{|c|}{ Evaluation category } & \multicolumn{1}{|c|}{ Set of indicators } \\
\hline \multirow{2}{*}{ 1. Bank reliability assessment } & Rate of deposit risk \\
\cline { 2 - 2 } & Capital adequacy \\
\hline \multirow{2}{*}{$\begin{array}{l}\text { 2. Bank profitability } \\
\text { assessment }\end{array}$} & Net put and call \\
\cline { 2 - 2 } & Interest margin \\
\cline { 2 - 2 } & Average cost rate of attracted deposit funds \\
\hline \multirow{2}{*}{$\begin{array}{l}\text { 3. Assessment of efficiency of } \\
\text { deposit resources use }\end{array}$} & Use factor of attracted deposit funds \\
\cline { 2 - 2 } & Effectiveness ratio of use of attracted deposit funds \\
\cline { 2 - 2 } & Effectiveness of deposit operations \\
\hline
\end{tabular}

Source: Authors.

The deposit policy of the commercial bank will be effective if there is an accomplishment of all these indicators, or their established statutory values, or the values provided for by the business plan. This will allow commercial banks to assess deposit risks, effectively conduct deposit policy in the future, based on the ratio of deposit resources volume with its structure, term structure of deposits and assets, and thereby, ensure profitability of commercial banks and liquidity of their activities.

\section{Conclusion}

Scientific approaches, proposals on organizational bases and methodological recommendations on deposit policy assessment are aimed at effective work of commercial banks to attract and use deposit funds, and identify reserves to increase profitability and liquidity of their activities.

The results of the study can be used in the commercial banks activities in the process of formation and implementation of deposit policy. They can also be used in research and higher education institutions for the further development of the banking theory. 


\section{References}

1. G.N. Beloglazova, Development strategy of the regional segment of the banking system. Banking, 2, 28-31 (2011). [in Rus.].

2. V.E. Kroliveckaya, L.P. Kroliveckaya, I.V. Soldatenkova, Credit and banking system of Russia at present stage. Journal of Legal and Economic Studies, 1, 128-132 (2018). [in Rus.].

3. O.I. Lavrushin, On modernization of regulation and new models of banking business development. Economy. Taxes. Law, 11(3), 14-19 (2018). DOI: 10.26794/1999-849X-2018-11-3-14-19. [in Rus.].

4. S.B. Kovalenko, Topical issues of banking sector development. In Sukiasyan A.A. (Ed.), Improving the methodology of knowledge for the science development: Collection of articles of International Research-to-Practice Conference Part 1 (pp. 108-110). Ufa: Aeterna (2017). [in Rus.].

5. C.B. Kovalenko, P.G. Shernin, Deposit insurance systems in the Russian Federation, Baltic countries and CIS countries. Bulletin of Saratov State Socio-Economic University, 1(65), 34-41 (2017). [in Rus.].

6. A.A. Martens, N.O. Derkach, Deposit policy as a basic element of commercial bank funding. In O.N. Shirokov (Ed.), Education and science: Modern trends (pp.140-150). Cheboksary: CNS «Interactive plus» (2018). [in Rus.].

7. A.A. Maslova, N.N. Martynenko, Deposit policy of a commercial bank and stereotypes of its development in an unstable economy. Modern Science: Topic Issues of Theories and Applications, 7, 55-57 (2017). [in Rus.].

8. A.N. Nikulina, A.A. Abalakin, Deposit policy of commercial banks: Tools, problems, prospects. Economy and Management Issues, 4(44), 62-65 (2015). [in Rus.].

9. G.S. Panova, Banks and banking business in Russia in the face of international sanctions. Obozrevatel - Observer, 12(311), 94-105 (2015). [in Rus.].

10. E.V. Novatorov, V.D. Novitskaya, Modification and empirical testing of SERVQUAL service quality measurement methodology with reference to banking services. Marketing and Finances, 1, 22-32 (2012). [in Rus.].

11. A. Parasuraman, V.A. Zeithaml, L.L. Berry, A conceptual model of service quality and its implications for future research. Journal of Marketing, 49(4), 41-50 (1985).

12. A. Parasuraman, V.A. Zeithaml, L.L. Berry, SERVQUAL: A multiple-item scale for measuring consumer perceptions of service quality. Journal of Retailing, 64(1), 12-40 (1988).

13. O.D. Zhilan, M.R. Danilova, Deposit policy influence on financial sustainability of commercial banks. Baikal Research Journal, 7(4), 4 (2016). DOI: 10.17150/2411-6262.2016.7(4).4. [in Rus.].

14. M.S. Maramygin, D.A. Suplakov, Managing the liquidity risk of a bank. Upravlenets, 9-10(37-38), 46-50 (2012). [in Rus.].

15. V.S. Potapov, M.A. Potapova, Management of attracted resources as a basis of the deposit policy of commercial bank. Economy Vector, 6(12), 38 (2017). [in Rus.].

16. V.A. Savinova, T.E. Borlakova, Evaluation of the development of the bank's operations to attract financial resources. Economic Sciences, 165, 96-102 (2018). [in Rus.].

L.I. Yuzvovich, E.A. Trofimova, M.S. Maramygin, A.V. Lebedev, Improving the assessment of commercial bank performance in the context of interbank competition (Ural University Publishing House, Ekaterinburg, 2018). [in Rus.]. 